\title{
Use of Boron for the Control of Eutypa Dieback of Grapevines
}

\author{
P. E. Rolshausen and W. D. Gubler, University of California, Department of Plant Pathology, One Shields Avenue, \\ Davis 95616, USA
}

\begin{abstract}
Rolshausen, P. E., and Gubler, W. D. 2005. Use of boron for the control of Eutypa dieback of grapevines. Plant Dis. 89:734-738.

Eutypa dieback is a perennial canker disease of grapevine (Vitis vinifera) caused by Eutypa lata. The fungus produces ascospores, which infect grapevines through pruning wounds during the dormant season. Management of the disease has been achieved with fungicide applications during the dormant period. However, no effective fungicide was available for this purpose after Benlate was withdrawn from the market. Boric acid (17.5\% a.i. boron), a potential alternative to Benlate, was tested in the present study against $E$. lata. The $\mathrm{EC}_{50}$ values for inhibition of mycelial growth and ascospore germination were 125 and $475 \mu \mathrm{g}$ of boric acid per ml (22 and $83 \mu \mathrm{g}$ a.i./ml), respectively. Two boron-based treatments were developed and tested in vitro and in four field trials during 2001 to 2003 . One product, biopaste, contained $5 \%$ boric acid $(8.75 \mathrm{mg}$ a.i./ml) in a commercial paste. The second product, bioshield, contained 5\% boric acid in a spore suspension of Cladosporium herbarum. Both products significantly reduced disease in vitro and in field trials in comparison with a water control treatment. Boron was not found to accumulate in leaves and shoots, but bud failure at the first node below the treated wound occurred at a higher rate than in untreated vines.
\end{abstract}

Additional keywords: fungicide screening, wood decay

Eutypa dieback is a severe disease of grapevine (Vitis vinifera L.) caused by the fungus Eutypa lata (Pers.:Fr.) Tul. \& C. Tul. (syn. E. armeniacae Hansf. \& M.V. Carter). The pathogen impacts grapevines by reducing vegetative growth and fruit yield (22). Siebert (34) reported that the overall loss in net income for wine grapes in California was estimated to be over $\$ 260$ million per annum.

E. lata infects grapevines through pruning wounds during the dormant season by means of ascospores released from perithecia after rainfall. The disease slowly kills the vine over several years (3). Pycnidia (anamorph Libertella blepharis A.L. Smith) are also produced by E. lata, but conidia or possible spermatia are not infectious (4). Several woody plant species are potential hosts for E. lata (5). The presence of $E$. lata perithecial stroma within and around Californian vineyards on many of these hosts has been reported, and these serve as a natural reservoir for $E$. lata inoculum (F. Trouillas, personal communication).

Disease management can be partially achieved by late pruning of vineyards. Pruning wounds can be susceptible for as

Corresponding author: P. E. Rolshausen
E-mail: perolshausen@ucdavis.edu

Accepted for publication 9 March 2005.

DOI: 10.1094/PD-89-0734

(C) 2005 The American Phytopathological Society long as 7 weeks (8), but the length of this period varies with the time of pruning and the age of the pruning cut $(8,25,27)$. Munkvold and Marois (25) determined that wound susceptibility to E. lata declined faster with high degree-day accumulation, due to wound healing by deposition of polymerized phenolic compounds in the opened wood vessels and concomitant establishment of an epiphytic microbial population on the wound surface. However, the large acreage of vineyards in California makes late pruning impractical for most growers. Also, late rains in the dormant season can trigger ascospore release and increase the risks of infection of newly pruned vineyards. Disease management is usually achieved by treating pruning wounds with fungicides or biological control agents $(6,12,14,21,23,24)$. Benlate (DuPont de Nemours \& Co., Wilmington, DE) was registered for E. lata control for 30 years, and field trials showed Benlate efficacy in preventing Eutypa dieback $(14,21,23)$. However, long-term protection of pruning wounds was not achieved because the product did not persist in woody tissue $(7,28)$. Therefore, several applications of Benlate were required to provide protection until complete healing of the wound, which was costly to growers.

Biocontrol agents were tested as an alternative method for control of E. lata. Bacillus subtilis (12), Fusarium lateritium Nees:Fr., and Cladosporium herbarum (Pers.:Fr.) Link (24) showed some potential activity in limiting the establishment of the pathogen. Unlike chemical applica- tions, which have an immediate effect, maximum protection from biocontrol agents requires colonization of the surface of the wound. Thus, there is a window of susceptibility after treatment, until the biocontrol agent is established well enough to prevent development of E. lata in the wounded tissue (6).

Boron (B) is an essential element for higher plants (1) and can be applied as soil dressings or as foliar sprays to limit boron deficiency $(1,9,11)$. Boron was also found to be active against several wood decay fungi $(10,16,18,33,35)$, and it is used in the timber industry to protect wood from termites and fungi (18) and in forestry to prevent infection of conifers by Heterobasidion annosum (Fr.) Bref. (=Fomes annosus (Fr.) Karst.) (16,33,35). Irelan et al. (17) also showed the efficacy of boric acid treatment to control infection of pruning wounds by $E$. lata in a field trial.

Our objective was to develop a control method for E. lata that is easily used by growers. The effect of boron on E. lata ascospore germination and mycelial growth was evaluated, and boron-based products were developed and tested in vitro and in field trials. Boron phytotoxicity was also evaluated, and boron levels were measured in grape leaves and shoots.

\section{MATERIALS AND METHODS}

In vitro evaluation of boron effect on E. lata growth and germination. An $E$. lata isolate (E31), obtained from a canker of grapevine cv. Chenin Blanc, was grown on potato dextrose agar (PDA). A 1-cmdiameter plug of mycelial agar was obtained from the actively growing margin of the colony and placed in the center of a petri plate supplemented with boric acid. Boric acid (17.5\% a.i. boron) was added to PDA after autoclaving to achieve final concentrations of $0,100,200,300,400$, and $500 \mu \mathrm{g} / \mathrm{ml}$. Five replicates were used per boric acid concentration. Plates were incubated at room temperature $\left(20 \pm 2^{\circ} \mathrm{C}\right)$ in the dark for 7 days. The radial growth was measured as the distance from the edge of the original plug to the outer margin of the colony. Two measurements were taken per colony.

Perithecial stroma of E. lata were collected from a vineyard in Napa County, $\mathrm{CA}$, and identified based on the morphological descriptions of Rappaz (29). Ascospores were obtained from perithecial stroma as described by Carter (4). Concentration was adjusted to approximately 500 ascospores per microliter with a hemacy- 
tometer (Hausser Scientific, Horsham, PA), and a $20-\mu \mathrm{l}$ aliquot was directly pipetted onto PDA medium amended with boric acid at 0, 200, 400, 600, 800, and 1,000 $\mu \mathrm{g} / \mathrm{ml}$. Petri dishes were left open under a laminar flow hood to allow drying of the droplet of water. Plates were incubated at room temperature $\left(20 \pm 2^{\circ} \mathrm{C}\right)$ in the dark for 2 days. Percent germination was determined by counting 250 ascospores per dish, with five replicates for each level of boric acid. An ascospore was counted as germinated when the germ tube was as long as the spore.

$\mathrm{EC}_{50}$ values (concentration required to reduce radial growth or germination by $50 \%$ ) of boron on ascospore germination and mycelial growth of $E$. lata were calculated by a regression of a probit of the percent inhibition for each fungicide concentration over the $\log _{10}$ of the fungicide concentration (13).

Formulation and in vitro evaluation of boron-based treatments. Boric acid efficacy was tested in vitro, in order to determine the concentration of boric acid at which control of E. lata could be achieved (30). One-year-old dormant grape canes cv. Cabernet Sauvignon were pruned, cut to blocks of $4 \mathrm{~cm}$ in length, and sterilized by autoclaving twice. Wood blocks were further dipped in sterile water for $15 \mathrm{~min}$ and then dipped in boric acid solutions for another 15 min under a laminar flow hood. Boric acid solutions were prepared by dissolving boric acid in sterile hot water at final concentrations of $0,0.1$, $0.5,1,5$, and $10 \%$ (wt/vol). Control wood blocks were dipped in water only. Wood blocks were then blotted on a sterile paper towel to remove excess liquid. French square bottles of $250 \mathrm{ml}$ (Fisher Scientific, Pittsburg, PA) filled with $15 \mathrm{ml}$ of PDA were autoclaved and laid flat on their side for cooling. A plug of agar from the edge of an E. lata culture was transferred into bottles and allowed to grow for 5 days prior to inserting the wood blocks into the bottles. Bottles were incubated for 4 weeks at room temperature $\left(20 \pm 2{ }^{\circ} \mathrm{C}\right)$, after which blocks were removed from the bottle and bark was stripped off. The wood blocks were surface sterilized by flaming, split open longitudinally, and five chips of wood $(3 \times 2 \times 2 \mathrm{~mm})$ were removed with the sterile blade of a knife and plated on PDA, with two replicates per wood block. The wood chips inoculated onto PDA represented roughly $1 \%$ of the total wood block. Petri plates were incubated at room temperature $\left(20 \pm 2^{\circ} \mathrm{C}\right)$ for a week. Boron treatments were evaluated as the percentage of wood blocks from which E. lata was recovered.

Based on the above results, a liquid and a paste boron formulation were developed. Bioshield consisted of a mixture of boric acid (5\% wt/vol) and a spore suspension of $C$. herbarum that had been challenged until the fungus could grow and survive at this boron concentration $(10,000$ spores per $\mu \mathrm{l})$. Biopaste consisted of a mixture of boric acid (5\% wt/vol) and a commercial paste (latex paint) used on trees as wound dressing and grafting seal (Doc Farwell's, Wenatchee, WA). Six treatments consisting of the water control, $5 \%$ boric acid, biopaste, bioshield, C. herbarum, and boron-free paste were evaluated simultaneously in vitro for control of E. lata as described previously (30).

Field evaluation of boron-based treatments. Trials were conducted during the 2001-2002 growing season in Yolo and San Joaquin counties and during 20022003 in Napa and San Joaquin counties in California. Grapevines were pruned in November to two buds, and treatments were sprayed (liquid) or painted (paste) onto pruning wounds. The treatments included water control, $5 \%$ boric acid, biopaste, bioshield, $C$. herbarum, and boron-free paste. All six treatments were evaluated by inoculating approximately 1,000 ascospores of $E$. lata directly onto pruning wounds at 1 and 10 to 12 days after treatment. Uninoculated pruning wounds were also included in order to determine the rate of natural disease occurrence in each vineyard. Twenty spurs were used per treatment and per timing of inoculation in Yolo and San Joaquin counties during the two growing seasons, and 50 spurs were used in the Napa County field trial. Spurs were harvested the following dormant season to determine the percent recovery of E. lata from the wood. The isolation techniques were identical to that described above for the in vitro assay. Results were represented as the mean percentage of infected spurs and the mean percent disease control at two times of inoculation. Percent disease control, Pdc, was calculated by $\mathrm{Pdc}=100(\mathrm{C} 1-\mathrm{C} 2) / \mathrm{C} 1$, in which $\mathrm{C} 1$ is the proportion of infected inoculated control spurs and $\mathrm{C} 2$ is the proportion of infected treated spurs. Mean percent disease control was calculated for each treatment at both times of inoculation and transformed to the arcsine square root of the fractional value. Each field trial was treated as a block (replication), and the data were analyzed using a two-way ANOVA. Tukey's test was used to determine which means were significantly different. All data analysis was performed using SAS (version 8.2, SAS Institute, Cary, NC).

Evaluation of boric acid phytotoxicity. Boron levels in shoots and leaves were evaluated for grapevines treated exclusively with water (control), biopaste, or bioshield for two consecutive years in Napa and Yolo county field trials (20012003) and three consecutive years in the San Joaquin field trial (2000-2003). Five grapevines per treatment were used to assess the phytotoxicity of boron-based treatments. Grapevines were pruned to two buds in November, and treatments were applied to each wound. At bloom, one shoot was sampled from each grapevine and leaves were separated from shoots. Samples were sent to the Division of Agriculture and Natural Resources (DANR) analytical lab at the University of California, Davis (UCD) for boron analysis, as described by Meyer and Keliher (20), and Sah and Miller (32).

Percent bud failure at the first node below the pruning wound was recorded for each treatment in 2003 in three field trials. Sixty replicates in San Joaquin and Yolo counties, CA, and 150 replicates in Napa County, CA, field trials were evaluated. Results were represented as the mean percentage of bud failure. Each field trial was treated as a block (replication), and the data were analyzed using a two-way ANOVA. Tukey's test was used to determine which means were significantly different. All data analysis was performed using SAS (version 8.2, SAS Institute, Cary, NC).

\section{RESULTS}

The $\mathrm{EC}_{50}$ values for inhibition of mycelial growth and ascospore germination were 125 and $475 \mu \mathrm{g}$ of boric acid per $\mathrm{ml}$, which corresponded to 22 and $83 \mu \mathrm{g}$ of boron per $\mathrm{ml}$, respectively.

$E$. lata grew directly on the watertreated wood blocks by producing a white flocculent mycelium. The isolation techniques performed yielded $100 \%$ recovery of E. lata from the control wood blocks. Fungal growth on wood blocks was not prevented with boric acid concentrations below or equal to $10 \mathrm{mg} / \mathrm{ml}(1.75 \mathrm{mg}$ a.i./ml) (data not shown), while at 50 $\mathrm{mg} / \mathrm{ml}(8.75 \mathrm{mg}$ a.i./ $\mathrm{ml})$, growth generally did not occur on the grape wood blocks and E. lata was recovered from only $10 \%$ of wood blocks. Therefore, the concentration of $50 \mathrm{mg} / \mathrm{ml}$ was chosen to develop the two boron-based treatments, biopaste and bioshield. Our results indicated full protection of wood blocks for 4 weeks in vitro when treated with biopaste and bioshield. However, E. lata totally colonized wood blocks when they were only treated with $C$. herbarum or boron-free paste (Fig. 1).

Treatment efficacies were evaluated based on data obtained from four field trials, and results are summarized in Table 1. Natural infection of control grapevines by E. lata ascospores was very low. However, ascospore inoculation of E. lata was successful and averaged $64 \%$ in the first inoculation, but decreased to $32 \%$ in the second inoculation 10 to 12 days following pruning. No significant difference was observed between inoculated control, boron-free paste, and $C$. herbarum at either inoculation time. Boron-based treatments significantly reduced infection by $E$. lata at both inoculation times.

Although boron levels varied depending upon year, vineyard location, and plant 


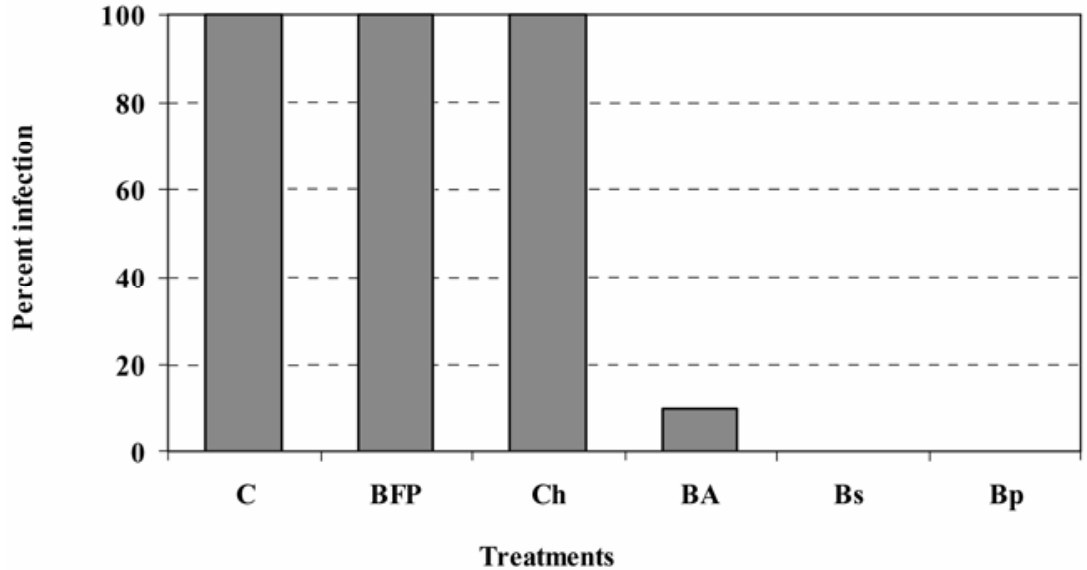

Fig. 1. In vitro performances of treatments in preventing Eutypa lata colonization of grape wood blocks over a 4-week period. Treatment efficacy was determined based on the percent recovery of $E$. lata from wood blocks. C, control (water treatment); BFP, boron-free paste; Ch, Cladosporium herbarum; BA, $5 \%$ boric acid; Bs, bioshield; Bp, biopaste.

Table 1. Results of field trials to evaluate boron efficacy for the control of Eutypa lata in San Joaquin and Yolo counties in 2001 to 2002 and in Napa and San Joaquin counties in 2002 to $2003^{\mathrm{x}}$

\begin{tabular}{|c|c|c|c|c|}
\hline \multirow[b]{2}{*}{ Treatment } & \multicolumn{2}{|c|}{ First inoculation } & \multicolumn{2}{|c|}{ Second inoculation } \\
\hline & $\begin{array}{l}\text { Mean percent } \\
\text { infection }^{\mathrm{y}}\end{array}$ & $\begin{array}{c}\text { Mean percent } \\
\text { disease control }\end{array}$ & $\begin{array}{l}\text { Mean percent } \\
\text { infection }^{y}\end{array}$ & $\begin{array}{l}\text { Mean percent } \\
\text { disease control }\end{array}$ \\
\hline Control & $3 \mathrm{~b}$ & $\ldots$ & $3 \mathrm{~d}$ & $\ldots$ \\
\hline Inoculated control & $64 \mathrm{a}$ & $\ldots$ & $32 \mathrm{a}$ & $\ldots$ \\
\hline Boron-free paste & $61 \mathrm{a}$ & $4.7 \mathrm{a}$ & $19 \mathrm{ab}$ & $40.6 \mathrm{a}$ \\
\hline $\begin{array}{l}\text { Cladosporium } \\
\text { herbarum }\end{array}$ & $32 \mathrm{a}$ & $50 \mathrm{a}$ & $17 \mathrm{abc}$ & $46.9 \mathrm{ab}$ \\
\hline Boric acid & $2 \mathrm{~b}$ & $96.9 \mathrm{~b}$ & 9 bcd & $71.9 \mathrm{abc}$ \\
\hline Bioshield & $4 \mathrm{~b}$ & $93.8 \mathrm{~b}$ & $7 \mathrm{dc}$ & $78.1 \mathrm{bc}$ \\
\hline Biopaste & $1 \mathrm{~b}$ & $98.4 \mathrm{~b}$ & $2 \mathrm{~d}$ & $93.8 \mathrm{c}$ \\
\hline
\end{tabular}

${ }^{x}$ Pruning wounds were inoculated with 1,000 ascospores of E. lata 1 and 10 to 12 days after treatment. Treatment efficacy was determined based on the percent recovery of E. lata from the treated spurs.

y Mean percentages of infected spurs. Values followed by a common letter were not significantly different according to Tukey's test $(\alpha=0.05)$.

${ }^{\mathrm{z}}$ Mean percent disease control (Pdc) was calculated as $\mathrm{Pdc}=100(\mathrm{C} 1-\mathrm{C} 2) / \mathrm{C} 1$, in which $\mathrm{C} 1$ is the proportion of infected control spurs, and $\mathrm{C} 2$ is the proportion of infected treated spurs. Values followed by different letters were significantly different as determined by analysis of variance (ANOVA) using Tukey's test $(\alpha=0.05)$.

tissue (Fig. 2), our observations did not indicate boron phytotoxicity on leaves, and our results did not show accumulation of boron in the herbaceous tissues of treated grapevines. However, bud failure at the first node below the treated wound was noticed in one of the field trials in 2002, but data were recorded only in three field trials conducted in 2003 (Table 2). The mean percentage of bud failure of the treated spurs was less than $10 \%$ with boron-free treatments and ranged from 23 to $27 \%$ with boron-based treatments. However, because of the limited number of replications used to run the statistical analysis, no differences were found between treatments. The spurs showing bud failure located at the first node position below the pruning wounds usually recovered by pushing two shoots at the basal bud position.

\section{DISCUSSION}

Our results clearly demonstrated the fungicidal activity of boron against $E$. lata.
Boron has previously been shown to affect many wood rotting fungi $(10,16,18,33,35)$, and is currently used in timber (18) and in forest $(16,33,35)$ industries. Boron products could potentially be used in viticulture to protect pruning wounds from E. lata. Boron-based products resulted in over $75 \%$ disease control 10 to 12 days following treatments. However, pruning wound susceptibility was reported to last several weeks $(8,25)$, and additional data are needed to evaluate the protective efficacy of boron products over that time period. The percent decrease of infection of inoculated control spurs from 64 to $32 \%$ after 10 to 12 days indicated that pruning wound susceptibility was affected by the age of the wound. Munkvold and Marois (25) also demonstrated that wound susceptibility was affected by the age of the wound as well as the time of pruning. However, they also concluded that wound susceptibility was not affected by the age of the wood. Therefore, boron-based products can be applied on small wounds of 1-year-old canes and on larger wounds of older wood and will provide the same effective protection against $E$. lata.

The mechanisms by which boron limits fungal growth have been studied in only a few pathosystems. Bowen and Gauch (2) reported that high levels of boron inhibited the growth of Saccharomyces cerevisae and Penicillium chrysogenum by inhibiting the glycolysis pathway. Aldolase was suspected to be the target of toxic levels of boron, making the fungi unable to utilize carbohydrates at a sufficient rate to maintain metabolic processes involved in growth and reproduction. Parker et al. (26) identified a mechanism by which Paecilomyces variotii could overcome the toxicity of boron by overproducing $\beta$-D-1,4glucosidase, thereby making more glucose available from the wood substrate for fungal metabolism. E. lata was determined to primarily deplete noncellulosic glucose of the hemicellulose fraction of the grapevine cell walls (31). However, further studies are needed to determine if dysfunction of glycolysis occurred with E. lata when treated with boron and/or if other mechanisms are involved in limiting fungal development.

Biocontrol agents tested as alternatives to fungicides have had mixed results $(6,24)$. Munkvold and Marois (24) observed a reduced infection rate in field trials when E. lata inoculation was conducted 14 days after treatment with $C$. herbarum, but our results did not show a reduction of infection rate when $E$. lata was inoculated 10 to 12 days after treatment with $C$. herbarum. The biology of $C$. herbarum has not been studied extensively, and the optimal conditions required for this organism to colonize pruning wounds may not always be reached under natural conditions, thereby offering limited control of $E$. lata.

The combination of fungicide and biocontrol agents to improve the duration and/or the efficacy of control of E. lata has also achieved limited success. Carter and Price (6) combined Benlate with Fusarium lateritium, but detected no significant differences in comparison with benomyl or $F$. lateritium treatments alone. McMahan et al. (19) also isolated a benomyl-resistant strain of $F$. lateritium, but field results are lacking to fully evaluate this combination. C. herbarum was able to grow on PDA medium amended with $5 \%$ boric acid (P. E. Rolshausen, unpublished). However, the combination of $C$. herbarum with boric acid did not significantly improved disease control over time, in comparison to boric acid alone.

Boron is an essential element for plants. It is required in developing leaves, stems, and flowers (1). Plants take up boron through their root systems and leaves, and foliar applications and soil dressings of boron are often used by growers to limit boron deficiencies and improve fruit set 

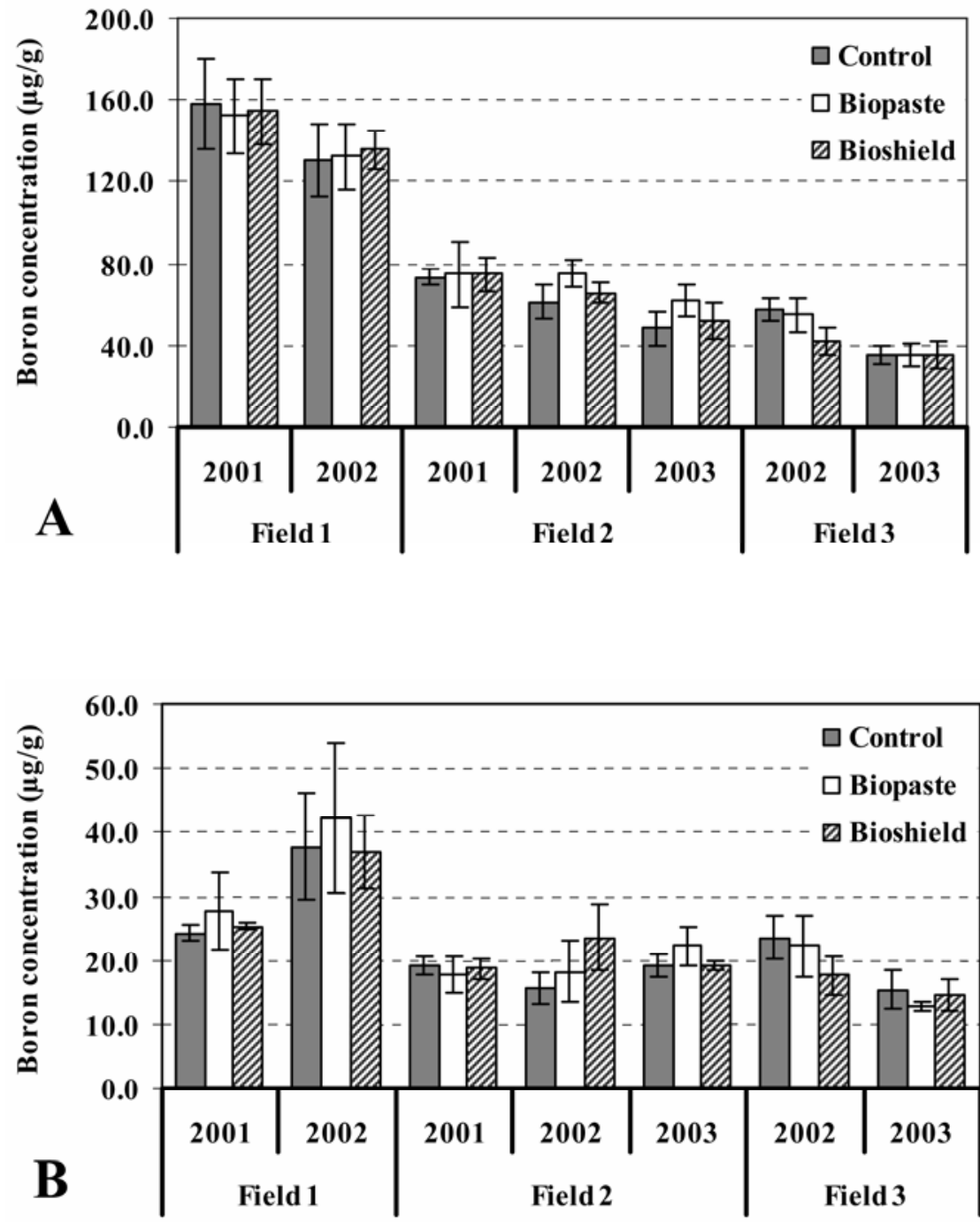

Fig. 2. Boron concentration $(\mu \mathrm{g} / \mathrm{g})$ in $\mathbf{A}$, leaves and $\mathbf{B}$, shoots of grapevines. Grapevines cv. Cabernet Sauvignon were pruned in the dormant season, and wounds were treated with water (control), biopaste, or bioshield for two or three consecutive years in three vineyards in California. Five replicates were used per treatment, and one shoot per grapevine was sampled at bloom. Bars represent the standard deviation of five replicates.

$(9,11)$. Christensen (9) reported that both boron deficiencies and toxicities were found in Californian vineyards due to soil characteristics, which would partially explain the field-to-field variability in boron levels observed in our trials. Our results also indicated higher boron levels in leaves than in shoots of grapevine. Gimmler et al. (15) also found accumulation of boron mostly in leaves sometimes to the level of phytotoxicity. The toxic threshold for boron in grapevines was reported at $100 \mu \mathrm{g} / \mathrm{g}$ of dry matter (15). This level was exceeded in the leaves of grapevines in one of our trials in Yolo County. However, no phytotoxicity was observed on the foliage of grapevines in this or any other trial in these studies. Boron levels were generally much lower in shoots than in leaves, and therefore the overall level of boron in dry matter may be below the phytotoxic level as reported by Gimmler et al. (15). Our observations indicated that the bud located at the first node below the pruning wound some-
Table 2. Effect of boron-based treatments on bud development of grapevine's spurs in three field trials located in Yolo, San Joaquin, and Napa counties, CA, in 2003

\begin{tabular}{lc}
\hline Treatments & $\begin{array}{c}\text { Mean percent } \\
\text { bud failure }\end{array}$ \\
\hline Control & $6 \mathrm{ab}$ \\
Inoculated control & $6 \mathrm{ab}$ \\
Boron-free paste & $6 \mathrm{ab}$ \\
Cladosporium herbarum & $3 \mathrm{~b}$ \\
Boric acid & $26 \mathrm{ab}$ \\
Bioshield & $23 \mathrm{ab}$ \\
Biopaste & $27 \mathrm{a}$ \\
\hline
\end{tabular}

${ }^{\mathrm{z}}$ Mean percentage of bud failure located below the treated wound. Values followed by different letters were significantly different as determined by Tukey's test $(\alpha=0.05)$.

walls of wood, and several system fixations have been devised to modify the wood properties and limit the natural diffusibility and leachability of boron on wood surfaces, and therefore increase protection against wood decay organisms.

Treatment of pruning wounds with boron offers an effective, economical, and environmentally safe management strategy to control E. lata in vineyards. However, formulations have to be optimized in order to increase the duration of control on the surface of wounds and limit putative effect on bud failure of grapevines. Potentially, boron-based treatments could be used on several cultivated crops on which E. lata was found to be pathogenic (5).

\section{ACKNOWLEDGMENTS}

This research was supported by the California Competitive Grant Program for Research in Viticulture and Enology, the American Vineyard Foundation, and the USDA Viticulture Consortium. We thank Ken Dell, Tom Miller, and Lynn Epstein for sharing their competence in statistical analysis and Tom Gordon and Jerry Uyemoto for providing advice on the writing of this manuscript.

\section{LITERATURE CITED}

1. Blevins, D. G., and Lukaszewski, K. M. 1998. Boron in plant structure and function. Annu. Rev. Plant Physiol. Plant Mol. Biol. 49:481500 .

2. Bowen, J. E., and Gauch, H. G. 1966. Nonessentiality of Boron in fungi and the nature of its toxicity. Plant Physiol. 41:319-324.

3. Carter, M. V. 1957. Eutypa armeniacae Hansf. \& Carter, sp. nov., an airborne vascular pathogen of Prunus armeniaca L. in Southern Australia. Aust. J. Bot. 5:21-35.

4. Carter, M. V. 1991. The status of Eutypa lata as a pathogen. Monograph - Phytopathological Paper No. 32. International Mycological Institute, Surrey, UK.

5. Carter, M. V., Bolay, A., and Rappaz, F. 1983 An annotated list and bibliography of Eutypa armeniacae. Rev. Plant Pathol. 62:251-258.

6. Carter, M. V., and Price, T. V. 1975. Biological control of Eutypa armeniacae. III A comparison of chemical, biological and integrated control. Aust. J. Agric. Res. 26:537-543.

7. Carter, M. V., and Price, T. V. 1977. Explanation of the failure of a commercial scale application of benomyl to protect pruned apricot trees against Eutypa dieback disease. Aust. J. Exp. Agric. Animal Husbandry 17:171-173.

8. Chapuis, L., Richard, L., and Dubos, B. 1998. Variation in susceptibility of grapevine pruning wound to infection by Eutypa lata in south- 
western France. Plant Pathol. 47:463-472.

9. Christensen, P. 2001. Pour on the Boron. Grape Grower Magazine, May: 13-17.

10. Cookson, L. J., and Pham, K. 1995. Relative tolerance of twenty Basidiomycetes to boric acid. Material Organismen 29:187-196.

11. Dye, M. H., Buchanan, L., Dorofaeff, F. D., and Beecroft, F. G. 1984. Boron toxicity in peach and nectarine trees in Otago. N.Z. J. Exp. Agric. 12:303-313.

12. Ferreira, J. H. S., Matthee, F. N., and Thomas, A. C. 1991. Biological control of Eutypa lata on grapevine by an antagonistic strain of $\mathrm{Ba}$ cillus subtilis. Phytopathology 81:283-287.

13. Finney, D. J. 1971. Probit Analysis. Cambridge University Press, Cambridge.

14. Gendloff, E. H., Ramsdell, D. C., and Burton, C. L. 1983. Fungicidal control of Eutypa armeniacae infecting concord grapevine in Michigan. Plant Dis. 67:754-756.

15. Gimmler, H., Degenhardt, B., Lang, S., and Track, C. 1998. Uptake of sodium, boron and heavy metals from alkaline top layer and translocation to leaves and lower roots of Vitis vinifera during a long time duplex study. J. Appl. Bot. 72:191-202.

16. Graham, D. A. 1971. Evaluation of Borax for prevention of annosus root rot in California. Plant Dis. Rep. 55:490-494.

17. Irelan, N., Gubler, W. D., and DeScenzo, R. 1999. Efficacy testing of Eutypa chemical and biological control candidates with DNA-based diagnostics. Winegrowing, January-February: 47-56.

18. Kartal, S. N., Yoshimura, T., and Imamura, Y. 2004. Decay and termite resistance of borontreated and chemically modified wood by in situ co-polymerisation of allyl glycidyl ether
(AGE) with methyl methacrylate (MMA). Int. Biodeterioration Biodegradation 53:111117.

19. McMahan, G., Yeh, W., Marshall, M. N., Olsen, M., Sananikone, S., Wu, J. Y., Block, D. E., and VanderGheynst, J. S. 2001. Characterizing the production of a wild-type and benomyl-resistant Fusarium lateritium for biocontrol of Eutypa lata on grapevine. J. Ind. Microbiol. Biotechnol. 26:151-155.

20. Meyer, G. A., and Keliher, P. N. 1992. An overview of analysis by inductively coupled plasma-atomic emission spectrometry. Pages 473-505 in: Inductively Coupled Plasmas in Analytical Atomic Spectrometry. A. Montaser and D. W. Golightly, eds.VCH Publishers, New York.

21. Moller, W. J., and Kasimatis, A. N. 1980. Protection of grapevine pruning wounds from Eutypa dieback. Plant Dis. 64:278-280.

22. Munkvold, G. P., Duthie, J. A., and Marois, J. J. 1994. Reductions in yield and vegetative growth of grapevines due to Eutypa dieback. Phytopathology 84:186-192.

23. Munkvold, G. P., and Marois, J. J. 1993. The effects of fungicides on Eutypa lata germination, growth, and infection of grapevines. Plant Dis. 77:50-55.

24. Munkvold, G. P., and Marois, J. J. 1993. Efficacy of natural epiphytes and colonizers of grapevine pruning wounds for biological control of Eutypa dieback. Phytopathology 83:624-629.

25. Munkvold, G. P., and Marois, J. J. 1995. Factors associated with variation in susceptibility of grapevine pruning wounds to infection by Eutypa lata. Phytopathology 85:249-256.

26. Parker, B. J., Veness, R. G., and Evans, C. S.
1999. A biochemical mechanism whereby Paecilomyces variotii can overcome the toxicity of the wood protectant, borate. Enzyme Microb. Technol. 24:402-406.

27. Petzoldt, C. H., Moller, W. J., and Sall, M. A 1981. Eutypa dieback of grapevine: Seasonal differences in infection and duration of susceptibility of pruning wounds. Phytopathology 71:540-543.

28. Price, T. V., and Carter, M. V. 1975. Persistence of benomyl in pruned apricot sapwood Aust. J. Agric. Res. 26:529-536.

29. Rappaz, F. 1987. Taxonomie et nomenclature des Diatrypacees a asques octospores. Mycol. Helv. 2:285-648.

30. Rolshausen, P. E., and Gubler, W. D. 1998. A new assay for screening fungicides for contro of Eutypa dieback of grapevine. (Abstr.) Phytopathology 88:S76

31. Rolshausen, P. E., Labavitch, J. M., Greve, L. C , and Gubler, W. D. 2003. In vitro changes in the major structural components of wood cell walls during decay by Eutypa lata. (Abstr.) Phytopathology 93:S129.

32. Sah, R. N., and Miller, R. O. 1992. Spontaneous reaction for acid dissolution of biological tissues in closed vessels. Anal. Chem. 64:230 233.

33. Schultz, M. E., Parmeter, J. R., and Slaughter, G. W. 1992. Long-term effect of treating true fir stumps with sodium tetraborate to control losses from Heterobasision annosum. West. J. Appl. For. 7:29-31.

34. Siebert, J. B. 2001. Eutypa: The economic toll on vineyards. Wines and Vines, April: 50-56.

35. Smith, R. S. 1970. Borax to control Fomes annosus infection of white fir stumps. Plant Dis. Rep. 54:872-875 